\title{
Amyloid arthropathy in patients undergoing periodical haemodialysis for chronic renal failure: a new complication
}

\author{
J MUÑOZ-GÓMEZ, ${ }^{1}$ E BERGADÁ-BARADO ${ }^{2}$ R GÓMEZ-PÉREZ, \\ E LLOPART-BUISÁN, ${ }^{1}$ E SUBÍAS-SOBREVÍA, ${ }^{2}$ J ROTÉS-QUEROL, \\ AND M SOLÉ-ARQUÉS ${ }^{3}$ \\ From the Departments of ${ }^{1}$ Rheumatology, ${ }^{2}$ Nephrology, and ${ }^{3}$ Pathology, Hospital Clínico y Provincial, \\ Barcelona, Spain
}

SUMmARY Seven patients (five male and two female) with chronic renal failure (CRF) treated by periodical haemodialysis presented with swelling and effusion of more than three months' duration in knees (four bilateral), shoulders (two, one of them bilateral), elbow (one), and ankle (one). Four had a carpal tunnel syndrome both clinically and electromyographically (three bilateral). All patients had hyperparathyroidism secondary to their CRF, which was not due to amyloidosis in any of them. The dialysis duration period varied from five to 14 years, with an average of 8.6 years. Amyloid deposits (Congo red positive areas with green birefringence under polarising microscopy) were shown in six of the seven synovial biopsy specimens of the knee, in five of the sediments of the synovial fluids, and in specimens removed during carpal tunnel syndrome surgery. No amyloid was found in the biopsy specimen of abdominal fat of six of the patients. The finding of amyloid only in the synovial membrane and fluid, and carpal tunnel, its absence in abdominal fat, and the lack of other manifestations of generalised amyloidosis (cardiomyopathy, malabsorption syndrome, macroglossia, etc.) and of Bence Jones myeloma (protein immunoelectrophoresis normal) raises the possibility that this is a form of amyloidosis which is peculiar to CRF treated by periodical haemodialysis.

Key words: amyloidosis, synovial amyloidosis, synovial fluid, carpal tunnel syndrome.

Various musculoskeletal disorders have been described in patients with chronic renal failure (CRF) treated by periodical haemodialysis. ${ }^{1}$ Among these are synovitis and bursitis due to sodium urate, calćium pyrophosphate, hydroxyapatite, and calcium oxalate microcrystals, ${ }^{2}$ bone and joint infections, osteonecrosis, carpal tunnel syndrome ${ }^{3-5}$ soft tissue and vascular calcifications, and metabolic bone disease (hyperparathyroidism, osteomalacia, osteoporosis, osteosclerosis).

Other alterations have been described ${ }^{6}$ : microtraumatic olecranon bursitis caused by the arm position during haemodialysis, unexplained 'dialysis cysts' (small cystic lesions in the hand and wrist

Accepted for publication 18 February 1985.

Correspondence to Dr J Muñoz-Gómez, Servicio de Reumatología. Hospital Clínico y Provincial, C/Villarroel 170, 08036 Barcelona, Spain. bones), digital clubbing in one or more fingers induced by anoxia distal to the fistula, and aneurysm at the site of the shunt, with or without calcification.

Our relationship with the Nephrology Department in the follow up of CRF patients in a periodical haemodialysis programme enabled us to identify several patients with swelling and effusions that could not be explained by the above-mentioned causes.

The clinical picture in the first patient studied (case No 1) was a chronic swelling with large effusion in the knees and shoulders (similar to the 'shoulder pad sign'), which suggested the possibility of amyloid arthropathy. ${ }^{7}$

\section{Materials and methods}

CRF patients undergoing periodical haemodialysis, with persistent swelling and effusion in the knee 
joint of more than three months' duration, were sought.

Among 312 patients undergoing a programme of haemodialysis in the Nephrology Department seven such patients were found, where the articular problem could not be explained by any of the abovementioned causes.

Haemodialysis was performed by means of an artificial kidney with automatic supply, continuous flow, and without capillary filter reuse. The patients were given ascorbic acid (1 g) and vitamin B complex after each haemodialysis session in addition to continued treatment with aluminium hydroxide and 25-hydroxycholecalciferol.

A full clinical and radiological examination of all patients was completed, in which the synovial fluid was analysed on various occasions (leucocyte count, search for crystals by regular and compensated polarised light microscopy both in fresh synovial fluid and after alizarin red staining) and a knee synovial biopsy specimen was obtained with Polley's needle.

Synovial samples fixed in $10 \%$ formol and synovial fluid sediments (after centrifugation) were mounted in paraffin and the sections stained with Congo red and studied under polarising microscopy in search of green birefringence typical of amyloidosis. $^{8}$
Some of the samples were treated with potassiuno permanganate by Wright's technique, ${ }^{9}$ and in six ou? of seven patients a needle aspiration of abdominat fat $^{10}$ was performed.

\section{Results}

The group studied included five men and tw $\odot$ women aged from 33. to 62 years (mean age 50\% (Table 1). The aetiology for their chronic renat failure was: glomerulonephritis (two), backflow hydronephrosis (one), nephroangiosclerosis (one)w and unknown (three). No patient had renal amyळ loidosis.

The dialysis duration period varied from five to 14 years, with an average duration of 8.6 years.

Clinical examination of the patients showed swell ing and effusion in the major joints: knees (seven patients, four of them bilateral), shoulders (twQ patients, one of them bilateral), ankle (one patient) and elbow (one patient). The swellings were accomz panied by minor pain, their onset being therefore difficult to ascertain; during our observations their duration varied between six months and two years? Two patients presented with an acute crisis in knees, shoulder, and elbow, with very 'inflammatory' flefd during the crisis, which caused the patients to admitted and a culture of the fluid to be undertafer

Table 1 Clinical features of the patients studied

\begin{tabular}{|c|c|c|c|c|c|c|c|}
\hline $\begin{array}{l}\text { Patient } \\
\text { No }\end{array}$ & Sex & Age & $\begin{array}{l}\text { Approx. } C R F \\
\text { age }\end{array}$ & $\begin{array}{l}\text { Dialysis } \\
\text { (years) }\end{array}$ & Joint signs and duration & Carpal tunnel syndrome & Radiology \\
\hline 1 & $\mathbf{M}$ & 59 & 49 & 9 & $\begin{array}{l}\text { Persistent swelling } \\
\text { knees/shoulders more } \\
\text { than one year. Acute } \\
\text { crises shoulders, knee, } \\
\text { elbow }\end{array}$ & $\begin{array}{l}\text { Yes. Bilateral. } \\
\text { Operated both sides }\end{array}$ & $\begin{array}{l}\text { Geodes in shoulders. } \\
\text { Hyperparathyroidism }\end{array}$ \\
\hline 2 & $\mathbf{M}$ & 48 & $?$ & 10 & $\begin{array}{l}\text { Persistent swelling } \\
\text { knees and ankle, } \\
\text { two years }\end{array}$ & No & $\begin{array}{l}\text { Geodes in shoulders, } \\
\text { knees, and pubis. } \\
\text { Hyperparathyroidism }\end{array}$ \\
\hline 3 & $\mathbf{M}$ & 47 & 37 & 5 & $\begin{array}{l}\text { Persistent swelling } \\
\text { knees and right } \\
\text { shoulder, six months }\end{array}$ & $\begin{array}{l}\text { Yes. Bilateral. } \\
\text { Operated both sides }\end{array}$ & $\begin{array}{l}\text { Microgeodes in hands. } \\
\text { Hyperparathyroidism }\end{array}$ \\
\hline 4 & $\mathbf{M}$ & 54 & $?$ & 8 & $\begin{array}{l}\text { Persistent swelling } \\
\text { left knee, one year. } \\
\text { Right shoulder joint } \\
\text { pain }\end{array}$ & $\begin{array}{l}\text { Yes. Bilateral. } \\
\text { Operated both sides }\end{array}$ & $\begin{array}{l}\text { Geodes in knees, right } \\
\text { femur, and right shoulder } \\
\text { Hyperparathyroidism }\end{array}$ \\
\hline 5 & $\mathbf{F}$ & 62 & 50 & 9 & $\begin{array}{l}\text { Persistent swelling } \\
\text { both knees, one year. } \\
\text { Shoulder joint pains }\end{array}$ & Yes. Right operated & $\begin{array}{l}\text { Patella subluxation bilatera } \\
\text { Vertebral osteodystrophi }\end{array}$ \\
\hline 6 & $\mathbf{M}$ & 50 & $?$ & 5 & $\begin{array}{l}\text { Persistent swelling both } \\
\text { knees, one year. } \\
\text { Acute crises both } \\
\text { knees }\end{array}$ & No & $\begin{array}{l}\text { Arthrosis right knee } \\
\text { (meniscectomy) }\end{array}$ \\
\hline 7 & $\mathbf{F}$ & 33 & 19 & 14 & $\begin{array}{l}\text { Persistent swelling left } \\
\text { knee, six months. } \\
\text { Joint pains in shoulders, } \\
\text { ankles, right knee }\end{array}$ & No & Hyperparathyroidism \\
\hline
\end{tabular}


Table 2 Synovial fluid characteristics and amyloid deposits localisation of the patients studied

\begin{tabular}{|c|c|c|c|c|c|}
\hline Patient No & Synovial fluid & Amyloid deposits median nerve & Fat & Synovial membrane & Synovial fluid \\
\hline 1 & $\begin{array}{l}\text { Non-inflammatory. } \\
\text { Inflammatory in crises }\end{array}$ & $\begin{array}{l}\text { Positive. Annular ligament (1) } \\
\text { synovium (1) }\end{array}$ & Negative & $\begin{array}{l}\text { Positive. Mesothelial } \\
\text { hyperplasia }\end{array}$ & $\begin{array}{l}\text { Positive. Shoulder(s) } \\
\text { knee(s) }\end{array}$ \\
\hline 2 & Non-inflammatory & - & Negative & $\begin{array}{l}\text { Positive. Mesothelial } \\
\text { hyperplasia }\end{array}$ & Positive. Knec(s) \\
\hline 3 & Non-inflammatory & Positive. Perineural region (2) & Negative & $\begin{array}{l}\text { Positive. Fibrous } \\
\text { connective tissue }\end{array}$ & Positive. Knec(s) \\
\hline 4 & Non-inflammatory & Positive. Annular ligament (2) & Negative & $\begin{array}{l}\text { Positive. Mesothelial } \\
\text { hyperplasia }\end{array}$ & Positive. Knee \\
\hline 5 & Non-inflammatory & Positive. Perincural region & Negative & $\begin{array}{l}\text { Positive. Non-specific } \\
\text { chronic synovitis }\end{array}$ & Positive. Knee(s) \\
\hline 6 & $\begin{array}{l}\text { Slight inflammatory. } \\
\text { Severe in crises }\end{array}$ & - & Negative & $\begin{array}{l}\text { Negative. Mesothelial } \\
\text { hyperplasia }\end{array}$ & Not done \\
\hline 7 & Non-inflammatory & - & Not done & Positive. Normal & $\begin{array}{l}\text { Negative. Knec. Small } \\
\text { amount }\end{array}$ \\
\hline
\end{tabular}

to check the possibility of an infection in the joints, but the results were negative. Between the crises there was persistence of the effusions with minor pain and low cellularity. Four patients complained of pains in shoulders, with no visible swelling at any time.

Four patients presented with a carpal tunnel syndrome both clinically and electromyographically, bilateral in three of them.

Radiological signs of hyperparathyroidism or osteodystrophy, or both were seen in all the cases and were intense in three of them.

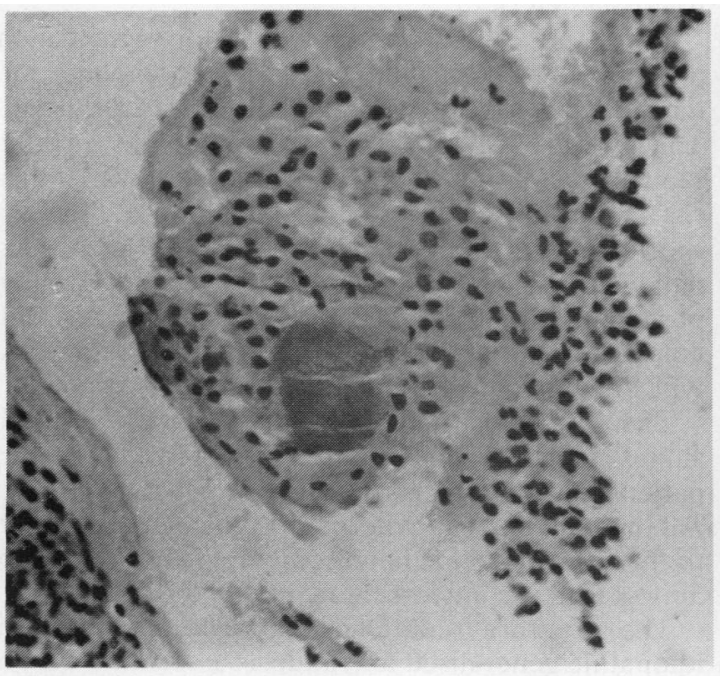

(a)
Three patients showed moderate or severe cystic lesions in shoulders (three), knees (two), and the superior branch of the pubic symphysis (one). One patient showed microgeodes, and another patient developed a bilateral external subluxation of the patella.

The blood biochemistry profile showed CRF and the classical alterations of secondary hyperparathyroidism in all patients. Serum protein electrophoresis was normal; serum immunoglobulins levels (IgA, $\mathrm{IgG}, \mathrm{IgM}$ ) were normal in all patients except for one with an IgG of $1760 \mathrm{mg} / 100 \mathrm{ml}(17.6 \mathrm{~g} / \mathrm{l})$ (normal

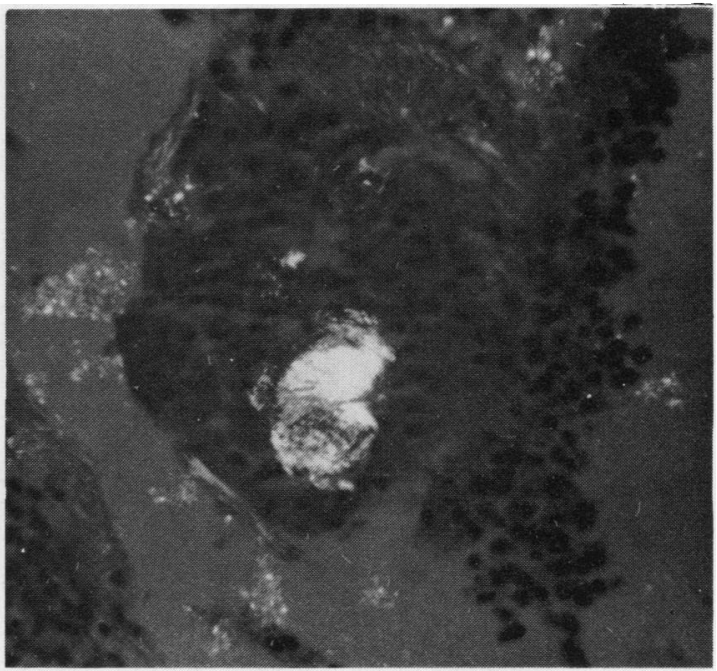

(b)

Fig. 1 Synovial tissue: (a) amorphous material deposition Congo red positive; (b) showing intense green birefringence under polarising microscopy. (Congo red, $\times 190$.) 
values $600-1500 \mathrm{mg} / 100 \mathrm{ml}(6-15 \mathrm{~g} / \mathrm{l}))$. Immunoelectrophoresis showed no qualitative abnormality of immunoglobulins nor the presence of light chains. These results excluded the presence of a Bence Jones myeloma in our patients.

The synovial fluid was 'non-inflammatory' in six patients $\left(<2000\right.$ leucocytes $\left./ \mathrm{mm}^{3}\left(2 \times 10^{9} / 1\right)\right)$, and the remaining fluid showed moderate inflammatory characteristics (around $5000 \mathrm{cells} / \mathrm{mm}^{3}\left(5 \times 10^{9} / \mathrm{l}\right)$ ). Two patients who suffered an occasional acute crisis showed very cellular fluids during these crises, fluctuating between 8000 and 103000 cells $/ \mathrm{mm}^{3}$ $\left(8-103 \times 10^{9} / 1\right)$ with an average of 30000 leucocytes/ $\mathrm{mm}^{3}\left(30 \times 10^{9} / 1\right)$.

No crystals were observed in any of the fluids, either in the unstained examination or after alizarin red staining.

The histological study (Table 2) of the synovial biopsy specimens showed amyloid deposits (Figs 1a and $1 \mathrm{~b}$ ) in six patients (Congo red positive areas with green birefringence); the other findings varied greatly: slight mesothelial hyperplasia (four patients, one of them amyloid negative), non-specific chronic synovitis (one), fibrous connective tissue (one), and normal (one).

The presence of amyloid in the synovial fluid sediment (Fig. 2) was proved in five of the six

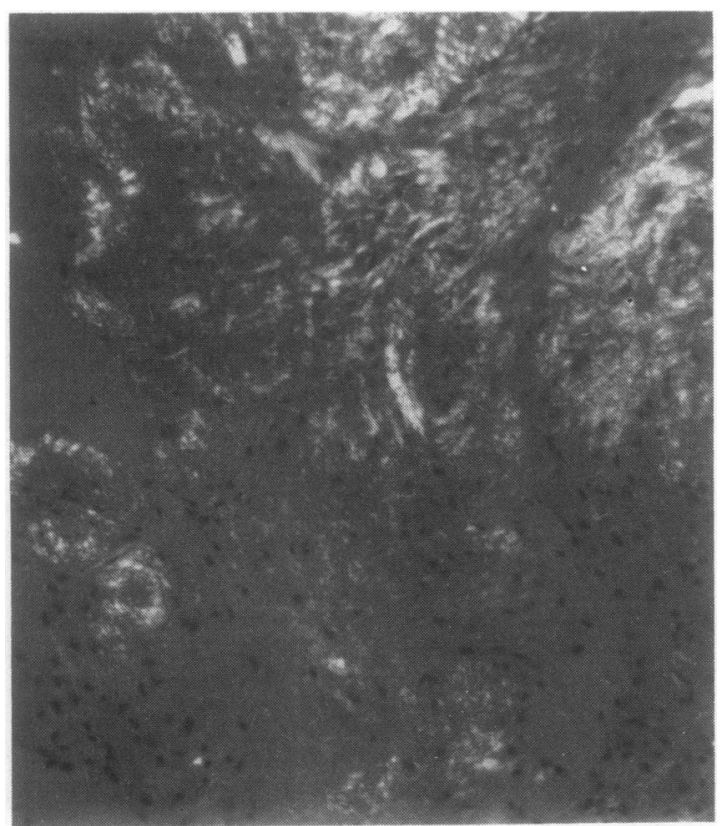

Fig. 2 Synovial fluid centrifugate. Multiple deposits of Congo red positive material with green birefringence. (Polarising microscopy, Congo red, $\times 100$.) patients studied (fluid from the knees in six occas sions, from the shoulder in one); the negative flui showed amyloid in the synovium. No fluid wat studied in the seventh patient (No 6) with af amyloid negative synovial biopsy specimen.

This patient had a clinical picture similar to that of the others, with swelling and effusion in both knee for a little over one year, treated with aspiration and injections of a depot corticosteroid every three tक four months. The patient had been referred from another hospital, and subsequent checks for the presence of amyloid in the effusion were not possible.

Surgery was performed on four of the patient with a carpal tunnel syndrome (two of them bilat eral), showing amyloid deposits in all of them (in the annular ligament in two, in the perineural region in two, and in the synovium in another).

A biopsy specimen of the abdominal fat was take from six patients and proved amyloid negative in all of them.

Potassium permanganate staining was positive i⿺廴 all articular fluid sediments and in the perineura region for the only patient who had an operation fog carpal tunnel syndrome in which it was studied.

\section{Discussion}

Six of the patients had synovial amyloidosis, fouroo them with a carpal tunnel syndrome, a frequent location of the so-called primary amyloidosis, bu的 without any other manifestations of generalise $\$$ amyloidosis (cardiomyopathy, malabsorption, maco roglossia, etc.).

In patient No 6 the synovial biopsy specimen probably did not include any affected synovium, o the aetiology for this case might have been different. The positive results from the treatment of the samples by Wright's technique pointed towards this classification, but the lack of amyloid in the biopsy specimen of the abdominal fat, negative in the six patients in which it was sought and which is usually positive in primary and generalised amyloidosis, dif not allow us to classify these patients as having this type of amyloidosis.

The protein immunoelectrophoresis normaf values without light chains confirmed that ou patients did not suffer from a Bence Jones myeloman All the patients had hyperparathyroidism secondarf to their chronic renal failure, and this was not due $t \delta^{\circ}$ amyloidosis in any of them.

The literature to date has described patients wit idiopathic generalised amyloidosis associated with Bence Jones myeloma. In our patients the clinical picture was one of chronic synovitis affecting mainly knees and shoulders, showing amyloid deposits i 
synovial membrane and in the carpal tunnel, but without deposition in the abdominal fat or other manifestations of generalised amyloidosis; for these reasons we think that we are probably dealing with a form of amyloidosis which is peculiar to CRF treated with periodical haemodialysis.

We thank Dr A St J Dixon. Royal National Hospital for Rheumatic Diseases, Bath, England, for kindly reviewing the manuscript.

\section{References}

1 Massry S G. Bluestone R, Klinemberg J R, Coburn J W. Abnormalities of the musculoskeletal system in hemodialysis patients. Semin Arthritis Rheum 1975; 4: 321-49.

2 Hoffman G S, Schumacher H R, Paul H, Cimerian V. Calcium oxalate microcrystalline-associated arthritis in end-stage renal disease. Ann Intern Med 1982; 97: 36-42.

3 Clanet M. Mausat M. Durroux R, et al. Syndrome du canal carpien, ténosynovite amyloïde et hémodialyse périodique. $R e v$ Neurol (Paris) 1981: 137: 613-24.
4 Allien Y, Asensio G. Mailhe D, Baldet P, Mion C. Syndrome du canal carpien chez l'hémodialyse chronique. Approche étiopathogénique. A propos de 31 cas opérés. Rev Chir Orthop 1983; 69: 233-8.

5 Assenat H. Calemard E, Charra B, Laurent G. Terrat J C. Vanel T. Hémodialysé. Syndrome du canal carpien et substance amyloïde. Nouv Presse Med 1980; 24: 1715.

6 Resnick D, Niwayama G. Parathyroid disorders and renal ostcodystrophy. In: Resnick D, Niwayama G, eds. Diagnosis of bone and joint disorders. Philadelphia: Saunders, 1981: 1803-59.

7 Ignazak F T. Amyloidosis. In: Kelley W N, Harris E D. Ruddy S. Sledge C B. eds. Textbook of rheumatology. Philadelphia: Saunders, 1981: 1511-30.

8 Gordon D A. Pruzanski W. Ogryzlo M A. Synovial fluid examination for the diagnosis of amyloidosis. Ann Rheum Dis 1973: 32: 428-30.

9 Wright J R, Calkins E, Humphrey R. Potassium permanganate reaction in amyloidosis. Lab lnvest 1977; 36: 274-81.

10 Westermark P. Stenkvist B. Diagnosis of secondary arnyloidosis by fine needle biopsy of the skin. Acta Med Scand 1971; 190: 453-4.

\section{Book review}

\author{
A Practical Handbook of Joint Fluid Analysis. By \\ R A Gatter. Pp. 105. US\$ 24.75. Lea and Febiger: \\ Philadelphia. 1984.
}

Laboratory analysis of synovial fluid provides a firm diagnosis in only two types of arthritis: microbial infections and crystal synovitis. It can also identify a haemarthrosis and give some idea of the acuteness of synovial inflammation; but here the laboratory does not add very much to what is apparent from naked eye inspection of the fluid. The minimum requirements for the clinician dealing with rheumatic diseases are, therefore, facilities for the reliable identification of synovial crystals and infections.

Identification of synovial infections has so much in common with the requirements of other specialties that routine microbiology laboratories generally handle this adequately. Crystal identification, however, requires experience and hardware that is not so often available in routine laboratories. For this reason, many rheumatologists have found it necessary to equip themselves to carry out this investigation, and a generation of trainees is coming to regard this as an essential part of their experience.

An excellent account of all aspects of the examination of synovial fluids is included in the recent 10th edition of 'Hollander', this section being written by the editor himself-Dr Dan McCarty. Do we, therefore, need this new book on the same subject? I believe we do. This handy, slim volume of about 100 pages is well set out and includes excellent illustrations. Its place is beside the polarising light microscope in the outpatient department, and on the shelf of the clinical pathology laboratory. It needs to be within easy reach of both the beginner who cannot remember the optical properties of common crystals and also the more experienced, who will find useful information about such matters as the identification of injected corticosteroid material and other uncommon contaminants. There is a fund of other useful information about all aspects of synovial analysis.

I was surprised at two pieces of advice given. The first is to use an anticoagulant when taking fluid for crystal examination; I find that flecks of clot are useful to focus on and, by trapping crystals, provide an enriched area in which to search. Secondly, the author recommends using a high power oil immersion lens when studying 'wet' preparations for crystals. This may increase the sensitivity of the test, but it must also make it more complicated and time consuming.

However, in general the advice given is clear, comprehensive, and essentially practical (the author's advice on arthrocentesis includes keeping a small artery forceps handy for removing needles when switching syringes or extracting the distal fragment of a broken needle!).

I recommend it.

HARRY CURREY

Editor 